Pascal K. Somé

Pascal K. Somé teaches linguistics at Université Paul Valéry, Praxiling, ICAR UMR 5191 CNRS-Montpellier 3, France. Email: pascalsome@noos.fr.
The Burkinabè novel: heterogeneous writing, texts located between written and oral forms

\title{
Heterogeneous writing, texts located between written and oral forms
}

A French person perusing some Burkinabè novels would undoubtedly be surprised or even baffled by tense transitions. These are often not typical, and the purists of the French language would unquestionably condemn them. Yet, these transitions express the potentials inherent in the French tense system. Some linguistic theories, like Benveniste's, if not used mechanically and sketchily, may help account for these "turbulence zones," as some people have labelled them. My paper aims to show how, in most Burkinabè novels, this tense transition game allows for switching from one tense to another: from the Past Perfect (PP) to the Simple Past (SP) and Pluperfect (PLP), from the Present PRES to the Imperfect (IMP), and from the Future (FUT) to the Conditional (COND). This takes place in all narrative spaces, in a perfect linguistic legality. Some have explained these often unpredictable transitions as being the result of a switch between, a telescoping, of two different types of narration, two enunciation points of view of the narrator (linked diegesis and autonomous diegesis). However, this switching-telescoping may also be interpreted as the narrator oscillating between a written narration and an oral narration. We see this phenomenon as a form of intrusion or irruption, not necessarily a conscious one, of orality into writing. Hence, Burkinabè novels are heterogeneous in nature, evolving between writing and orality, and this is one of the manifest trends of novel writing in Burkina Faso. Key words: Verbal temporality, semantics, discourse analysis, francophone literature.

\section{Introduction}

There are two attitudes towards the Burkinabè novel, as well as towards Burkinabè literature as a whole. The first one aims to foster it through clarifying its specificities, compared to African and/or French literature. The other one, it would seem, lies in devaluing it more or less explicitly, through pinpointing the various unorthodox grammatical forms it contains. My interest here takes a purely linguistic and nonnormative perspective, and is primarily concerned with investigating the potentialities and elasticity of the language, French language that is, as used in some Burkinabè novels.

My study corpus comprises 34 out of the 37 novels published between 1962 and 1995. The analysis focuses on the tense system, especially temporal transitions, some of which occur in ways that may surprise and even shock those more concerned with norms, and who therefore tend to condemn them categorically. My point is to delin- 
eate some of these phenomena and to study them in the light of the recent developments of E. Benveniste's (1966) famous theory on tense relations in the French verb. The explanatory hypothesis here will consist in linking up the phenomenon of temporal alternations, which are often predictable, with what may be considered as the dominant trend in the Burkinabè novel: heterogeneity.

For this purpose, I will first provide a typology of the narrators, based on their narratological status according to G. Genette's model. Then, I will concern myself with how the narratives of these narrators often alternatively rely on two types of diegetic modes - an autonomous diegesis with the simple past tense (SP), and a linked diegesis with the present perfect tense (PP). Often taking the shape of a telescoping, this alternation occurs within generalized competition between verbal tenses. The third part of the paper will show that two temporal sub-systems of the French language operate in this generalized competition.

\section{Enunciation and narratological typology of Burkinabè novels}

The typology of narrators ${ }^{1}$ concerned here looks back to Genette (1972: 252):

We shall differentiate between two types of narratives: one with a narrator who is absent in the story he recounts (example: Homer in The Iliad, or Flaubert in Sentimental Education), the other with a narrator who exists as a character in the story he recounts (example: Gil Blas, or Wuthering Heights). I call the first type, for obvious reasons, heterodiegetic, and the second homodiegetic. ${ }^{2}$

Genette's interest here lies almost exclusively in extradiegetic (heterodiegetic/homodiegetic) narrators. ${ }^{3}$ These are narrative levels of the main narrative (first narrative). The term "intradiegetic narrator" refers to narrators included in the main narrative. This is the case when a character becomes a narrative level of its own. If, to this narratological criterion, we add the enunciation parameter of verbal temporality, we may obtain the following synthetic table as a categorization of Burkina novels (see opposite page).

\section{Heterodiegetic narrators}

The table reveals a clear predominance of this type of narrators in Burkinabè novels (30/36), with the enunciation operating under two main modes, if we consider the basic narrative tense. Twenty three novels are built on the Simple Past/Imperfect (SP/ IMP) pair associated with the third person (P3), considered from the enunciation point of view as a "non-person," unlike the first (P1) and second (P2) persons. Conjugated on the Present/Present (PRES/PRES) basis, this "non-person enunciation" is the second most used mode in seven novels. ${ }^{4}$ 
EXTRADIEGETIC NARRATORS (except Sadjo) ${ }^{5}$

\begin{tabular}{|c|c|c|c|}
\hline \multicolumn{2}{|l|}{ Heterodiegetic } & \multicolumn{2}{|l|}{ Homodiegetic } \\
\hline $\begin{array}{l}\text { Simple past tense } \\
+ \text { third person } \\
(S P+P 3)\end{array}$ & $\begin{array}{l}\text { Present } \\
+ \text { third person } \\
(P R E S+P 3)\end{array}$ & $\begin{array}{l}\text { Simple past (present perfect) } \\
+ \text { first person } \\
(S P(P P)+P 1)\end{array}$ & $\begin{array}{l}\text { Present } \\
+ \text { first person } \\
\text { (PRES + P1) }\end{array}$ \\
\hline La dérive & L'enfer & Affaire & Bill \\
\hline Champ & Les carnets & Le miel amer & \\
\hline Zaka & Les vertiges & Pour nous & \\
\hline Crépuscule & Le procès & L'épave & \\
\hline Le fil & Haro & Le héraut & \\
\hline Les dieux & Le retour & & \\
\hline Le geste & Père & & \\
\hline \multicolumn{4}{|l|}{ Patarbtaalé } \\
\hline \multicolumn{4}{|l|}{ Au gré } \\
\hline \multicolumn{4}{|l|}{ Le mal } \\
\hline \multicolumn{4}{|l|}{ Le fils aîné } \\
\hline \multicolumn{4}{|l|}{ Adama } \\
\hline \multicolumn{4}{|l|}{ Indésirables } \\
\hline \multicolumn{4}{|l|}{ Dessein } \\
\hline \multicolumn{4}{|l|}{ Aurore } \\
\hline \multicolumn{4}{|l|}{ La montagne } \\
\hline \multicolumn{4}{|l|}{ Le carnaval } \\
\hline \multicolumn{4}{|l|}{ La défaite } \\
\hline \multicolumn{4}{|l|}{ Le nombril } \\
\hline \multicolumn{4}{|l|}{ Le parachutage } \\
\hline \multicolumn{4}{|l|}{ Rougbêinga } \\
\hline \multicolumn{4}{|l|}{ Le geste } \\
\hline \multicolumn{4}{|l|}{ Campus } \\
\hline 23 novels & 7 novels & 5 novels & 1 novel \\
\hline 30 novels & & 6 novels & \\
\hline 36 novels & & & \\
\hline
\end{tabular}

\section{Homodiegetic narrators}

The most represented trend (5 novels) combines the first person and the Simple Past (SP) and/or the Present Perfect/Imperfect (PP/IMP) pair. While in Le miel amer ("Bitter honey", 1985), Affaire de coeur ("A matter of heart", 1990), and L'épave d'Absouya ("The wreck of Absouya", 1994), the two narrative tenses (Simple Past and Present Perfect) compete $^{6}$ impressively, the Simple Past dominates in Pour nous la galère ("For us the 
drudge", 1990), and PP holds primacy in Le héraut têtu ("The obstinate herald", 1999). The PRES/PRES combination only occurs in Bill l'espiègle ("Bill, the mischieveous", 1993).

This typology shows that the Burkinabè novel (1962-1995) owes much to the 19th century French realistic novel, with extra-heterodiegetic narrators narrating their stories in P3 and based on the SP/IMP pair: that is, 2/3 of the novels of the study corpus. Except Patrick Ilboudo (4 novels), Jean-Baptiste Somé (2 novels), Kollin Noaga (2 novels), Dieudonné Samou Tamini (1 novel), Pierre Barrot et Seydou Drame (1 novel), all the authors resort to this combination. The remaining $1 / 3$ novels split between PRES/PRES narrations (P3, or even P1) and SP(PP)/IMP (P1) narrations, respectively 8 against 6 novels.

This confirms Roland Barthes's (1972: 25) observation more than 50 years ago about SP being a "narrative corner stone": "Dropped from spoken French, the simple past (a narrative corner stone) always signals art; it is part of the ritual of the belles-lettres. It is no longer responsible for expressing tense." ${ }^{8} \mathrm{SP}$ (the most used basic tense) is tenacious in the Burkinabè novel. An author may decide to leave it aside, but it always finds a way to re-emerge, for one reason or another. It may even occur in the dialogue passages of the novels. The following enunciation from Le procès du muet ("The trial of the deafmute", 1987: 224-226) illustrates these irruptions of SP in PRES/PRES narratives:"

Having risen early Batolo goes to wake his uncle up. They have an appointment with historical truth this morning at the Court of Justice where the permanent popular revolutionary tribunal has to give the verdict in the case opposing the African Economic Union to Biga Zambsoiba and Pass Yam [...]. Coming up to the street that leads to the Court of Justice, they meet a human tide that had already invaded the courtroom [...] a rural market or flee market day hubbub filled the atmosphere. The radio hosts add their vitriolic comments to the din. Suddenly silence gave way to the voice of the judge presiding over the tribunal. [...] A tempest of exclamations follows the public announcement of the trial. Batolo and Ram Nogdo who are now lost in the rally must be a little satisfied. ${ }^{10}$

The fact remains that SP regularly faces harsh competition from PP, not just in P1 novels, but also in P3 ones. PP also competes against PLP (Pluperfect) in narrative passages, while PRES does so against IMP in descriptive ones. Actually, this is a generalized competitive game obtaining even in grammatical and enunciation micro-structures such as subordinate clauses and free indirect speeches. It also involves other tenses such as the Future (FUT) and Conditional (COND). ${ }^{11}$

The general hypothesis used here to analyze temporal transitions in Burkinabè novels is that there is an alternation, or even a telescoping between two types of diegeses (autonomous and linked), between the two tense sub-systems of the French verbal system. 


\section{Narrators between autonomous diegesis and linked diegesis}

\section{From the Benvenistian dichotomy to the tri-partition of J. M. Adam and F. Revaz}

Benveniste's fundamental intuition

In his famous article entitled "Les relations de temps dans le verbe français" ("Tense relations in the French verb") first published in 1946, Benveniste (1966: 238) states that "The tenses of a French verb are not used as components of a single system; they are distributed in two distinct and complementary systems." 12 For him, PP and SP constitute the marks, the indices of two enunciation levels, which he names "story" (story enunciation) and "discourse" (discursive enunciation):

Story enunciation, currently reserved for the written language, characterizes the narration of past events. These three terms, "narrative," "event," and "past" are also to be noted. They concern the presentation of facts that occurred at a certain point in time, without the intervention of the speaker in the narrative [...]. We must understand discourse in its broadest sense: any enunciation implying a speaker and a hearer, with the first intending to influence the second in some way [...]. Any time a discourse occurs within a story narrative, when the narrator for instance repeats the words of a character or steps in to pass judgments on the events, there is a shift to a different temporal system, that of the discourse. (Benveniste 1966: 242) ${ }^{13}$

However, we must recall that for Benveniste, such texts are very rare that may exclusively belong to one or the other level of enunciation in its pure state. As a rule, the enunciations tend to alternate or mix the two modes: "The nature of language is to allow for these instantaneous transfers," asserts Benveniste (1966: 242). ${ }^{14}$ According to this theory, enunciation bi-partition goes along with a bi-partitioning of the verbal tenses, as recapped in the table below:

\begin{tabular}{lllll} 
MODE & STORY & & DISCOURSE & \\
\hline Basic tenses & Simple tenses & Perfect tenses & Simple tenses & Perfect tenses \\
\hline & $\begin{array}{l}\text { Indeterminate } \\
\text { past tense }\end{array}$ & Past anterior & Present & Perfect \\
& Imperfect & Pluperfect & Future & Future anterior \\
\hline Other tenses & & & Imperfect & Pluperfect \\
\hline \multicolumn{7}{l}{ Conditional } & Perfect & Conditional & Perfect \\
\hline Tenses excluded & Present* & Perfect & Indeterminate & Past anterior \\
& & & past tense & \\
\hline Verbal persons used & & Anterior future & & \\
\hline Verbal persons excluded & 1st pers. & 2nd pers. & 1st pers. 2nd pers. & 3rd pers. \\
\hline
\end{tabular}

\footnotetext{
* Except the defining present
} 
A terminological confusion, for which Genette endorses part of the responsibility, has caused damage to Benveniste's theory. Perhaps for the sake of simplicity, the disseminators have easily tended to associate "story / story enunciation" with "narration / narrative". This has led to a radicalization of the distinction between the two enunciation modes, one of which is transformed into a textual mode. Jean-Michel Adam (1998) notes this abusive simplification with much surprise because Benveniste had written an explanatory note warning against it. ${ }^{15} \mathrm{H}$. Weinrich's book, Le temps (Tempus) ("Tense"), further expanded the confusion and dichotomy. Fifty years after the publication of Benveniste's paper, some French linguists decided to denounce the debasement of the theory, "to put an end to the narrative/ story pair" (see Adam 1997, 2005; Adam, Lugrin and Revaz 1998; Revaz 1996). With this, it has been possible to give back to the theory its explanatory power in the area of discourse analysis and textual analysis.

\section{To end with the narrative / discourse pair}

Seeking to explain that PP (narrative) and SP are not synonyms, Revaz (1996) asserts that grammatical tenses express two separate enunciating values. She has concerned herself with the Benvenitian dichotomy, from which she presents the two tenses (both being diegetic) as expressing two types of diegeses: a linked diegesis (PP) and an autonomous diegesis (SP). In so doing, she clearly reckons with Benveniste's note 2 , in accordance with Adam's explanation of it (see above). For her, Benveniste's theory should lead to a tri-partition and not a bi-partition:

Taking two diegetic modes into consideration seems to me useful in getting out of the deadlock of the two enunciation levels usually cited - discourse or comment vs. story or narrative) - as well as out of the two verbal sub-systems resulting from this [...]. By retaining the traditional enunciation levels, we indeed concede that PP is a "discourse" tense and SP a "story" tense. This rather strict dichotomy does not account with, for instance, the two values of PP, and therefore inevitably results in aberrations. Thus, A. M. De Both-Diez, [...] talks of a "discourse" PP and a "story" PP. To avoid any ambiguity, I propose the following three enunciation modes: direct, linked, autonomy (Revaz 1996: 190). ${ }^{16}$

This enunciation tri-partition also obtains in Adam $(1997,2005)$ and Adam, Lugrin and Revaz (1998) in the following schematic form:

\section{NARRATIVE MODES (diegesis)}

\begin{tabular}{lll}
\hline $\begin{array}{l}\text { Story enunciationstory narration } \\
\text { (autonomous diegesis) }\end{array}$ & $\begin{array}{l}\text { Discourse narration } \\
\text { (linked diegesis) }\end{array}$ & $\begin{array}{l}\text { Pure "discourse" } \\
\text { (direct interaction) }\end{array}$ \\
\hline & \multicolumn{2}{c}{ "discourse" enunciation" } \\
\hline
\end{tabular}


This table highlights the fact that Benveniste's initial opposition of enunciations hides a tri-partition involving a combination of an enunciation criterion (enunciation position) and a narratological criterion (diegesis): an autonomous diegesis ("story enunciation"), a linked diegesis (discursive enunciation), and direct interaction (discursive enunciation).

Direct interaction (pure discourse) is the "most direct locating mode, and its basic parameters are those of the verbal interaction: the primary deictic rooting I/you + here + now" (Adam, Lugrin and Revaz 1998: 88). ${ }^{17}$ However, in French, to create a past or a fictitious world, the temporal system offers two possibilities: "To create a past or a fictitious world, we have a choice between a diegesis operating on the present mode, that is, linked to the present of the narrator, and a diegesis operating on the non-present mode, that is, detached from the present of the enunciating voice." In French, these two diegeses correspond to the PP-SP opposition because, as Benveniste (1966: 244) expansively observes: "The temporal benchmark of the perfect [PP] is the moment of the discourse, whereas the benchmark of the indeterminate past [SP] is the moment of the event" (Adam, Lugrin and Revaz 1998: 90). ${ }^{18}$

The table below also found in Revaz (1996: 190-191) syntheses the three sub-systems ${ }^{19}$ with the main basic tenses:

\begin{tabular}{llll}
$\begin{array}{l}\text { TRADITIONAL LEVEL } \\
\text { of ENUNCIATION }\end{array}$ & "DISCOURSE" or "COMMENT" & "STORY" or "NARRATIVE" \\
\hline Enunciation modes & Interaction & Diegesis & \\
\hline Pivotal tenses 20 & Direct & Linked & Autonomous \\
\hline & Deictic Present & Diegetic & Simple past \\
& Imperfect & present perfect & \\
\hline Rooting marks & Performative & & \\
& I/you & Yesterday & Once upon a time \\
& Now & Last year & In those days \\
\hline
\end{tabular}

This review of Benveniste's theory is of crucial importance in analyzing the complexities of texts. Tri-partition is a key to explaining an important aspect of the competition game taking placing between verbal tenses in the bulk of Burkinabè novels. These narratives depend, in variable proportions, on the alternation between autonomous diegesis and linked diegesis, unlike in the French realistic tradition of novel writing where authors always choose between the two modes (see for instance Germinal (Zola), La curée (Balzac), L'étranger (Camus), or Regain (Giono). ${ }^{21}$ 


\section{From autonomous diegesis to linked diegesis, and vice versa}

This to and fro phenomenon between two types of diegeses obtains in SP and P1 novels as well as in P1, SP and/or PP ones. It also exists in "zero degree narrations" such as retrospective passages (analepsis or flashback) (see Zaka "La maison" ("Zaka 'Home'", 1991: 46), La dérive des Bozos ("The drift of the Bozos", 1988: 17-18) and Pour nous la galère ("For us the drudge", 1990: 77-78).

In SP + P3 novels

Zaka "La maison", Le fil des crevasses ("Thread of the crevasses", 1993), Le parachutage ("Parachuting" , 1988), Rougbêinga ("Rougbêinga" = the hero's nickname, 1990), Champ d'août ("August field", 1986) and La dérive des Bozos are the most representative novels of this trend. Compare this excerpt from Rougbêinga (148-153):

The crowd broke away silently. Neither the place nor the moment was appropriate for comments. Each will voice his viewpoint in his hut, with as scarce sounds as required by discretion.

The Coumandow has given to Liguidy's pages a large plate, a new storm lantern, six spoons, and a liter of wine. These were the usual gifts he made to his friend during big festivals or as a reward for the numerous services paid.

Surrounded by the notables of the neighborhoods and of the villages, Liguidy has listened religiously to the griots singing his praises. This soft rain was necessary to soothe the flames that had been burning in his veins since the news of the "crime of the Gourounsis."

"I have asked you to come so that I can tell you in plain words [...]. Liguidy has spoken. You may go back to your homes."

The notables have pledged their unconditional support to the Coumandow and to Liguidy. However, outside the palace, people had their own different opinions on the events, but they refrained from showing these..$^{22}$

In Rougbêinga after several pages of autonomous diegesis (SP) narration, the narrative ends up in the form of linked diegesis (PP). In Champ d'août there is a true and impressive regular telescoping between the two types of diegeses. The excerpt under consideration covers about ten pages, i.e. Champ d'août (60-69), but due to space considerations will not be cited in its entirety. Here is a sample reflecting the parts involving the narrator: ${ }^{23}$

Kiéta swore. Therefore the judge said to him [...]. Kiéta has added that sincerely speaking [...]. The judges therefore asked him [...]. The chairman of the court asked him [...]. One of the judges asked [...]. Kiéta answered [...]. The judge elaborated [...]. The old man has explained that [...]. He was explaining to 'his sons' that [...]. The old man has said $[\ldots]^{24}$ 
However, we must observe that this phenomenon of swinging between two diegetic modes under zero degree narration is extremely rare or almost absent in the following novels: Adama ou la force des choses ("Adama, or by force of circumstances", 1987), Crépuscule des temps anciens ("Twilight of the olden days", 1962), Le carnaval de la mort ("The carnival of death", 1995), On a giflé la montagne ("The mountain has been slapped", 1991), and Le mal de peau ("Ill at ease with her skin colour", 1992).

\section{In $S P / P P+P 1$ novels}

The novels concerned here are: Le miel amer, Affaire de coeur, L'épave d'Absouya, Le héraut têtu and Pour nous la galère. C. Caitucoli (1988: 261-275) has studied the first novel, Le miel amer. The same uncontrollable transitions between PP and SP obtain in Affaire de coeur (82). The narrator of L'épave d'Absouya is therefore similar to his counterparts in Affaire de coeur and Le miel amer. The following passage from L'épave d'Absouya (132138) illustrates this:

One night Fanta has gone away from the household. Bakary was watching her. He followed her from a distance and spied on her. Fanta has headed towards the high traffic road that ran through the neighbourhood [...]. Fanta has hurried [...]. She has reached there and she has asked for the Sleeper, the most comprehensive daily paper of the area. She bought it. Swiftly, she flipped through it and reached the pages dedicated to services [...]. She arrived home and rushed into her room. Uncle Bakary arrived [...]. Fanta began to cry, shedding warm tears. The sound has alerted the occupants of the household. Bakary's wives have run to the scene; the children too. Already, the neighbours began to worry [...]. Before departing, uncle Bakary has drawn near his sister and has said to her [...]. Firmly, she answered reassuringly [...]. And then she left. ${ }^{25}$

If the two types of diegeses telescope more frequently with extra-diegetic narrators, P1 narration cannot be said to be the determining cause. For instance, very frequently, the narrator of Pour nous la galère uses the autonomous diegesis mode, as indicated earlier.

One may argue that the preceding illustrates the fact that verbal temporality and temporal transitions constitute "a turbulence zone," but this will depend on one's understanding of this expression. If it is a euphemism hiding a normative grammatical judgment, then it is excessive. To say that with such temporal transitions, "it is Benveniste's reader who feels embarrassed because the simple past and the present perfect appear in the same sentence, without anything justifying the change in the enunciation (and this is not a case of accidental skid)" (Caitucoli 1988: 263), ${ }^{26}$ is tantamount to somewhat reducing the explanatory power of Benveniste's theory, which Adam's and Revaz's (Adam, Lugrin and Revaz 1998: 96) explanations clarify:

We have seen this through the example of Michel Leiris; the constant shifts from an SP narrative to a PP narrative (and of course the reverse) cannot be explained 
otherwise. If the two usages are mutually exclusive from the point of view of the position of the subject in the enunciation, on the contrary they attract each other from the point of view of the diegesis, to which each of them contributes. Their coexistence is therefore not as extraordinary or as absurd as some have claimed through applying Benveniste's and Weinrich's dichotomies a little too mechanically. $^{27}$

That these two verbal drawers, which are mutually exclusive on the level of the enunciation, mutually attract each other on the diegetic level is a sufficient argument to dispel the doubts about the narrators of Burkinabè novels committing grammatical offense. The transitions are perceived as untimely because they cannot be controlled by the existing grammatical or linguistic rules, which are often too quick in stigmatizing linguistic practices that do not abide by their provisions or models.

The hypothesis adopted here to account for the generally unforeseeable nature of the alternations / telescoping between autonomous diegesis (SP) and linked diegesis (PP) consists in considering the occurrences of "linked diegesis" as irruptions or sudden appearances of orality into written narratives. It would seem that the narrators' hearts, often taken for those of the authors, waver between two narrative modes (written and oral) in an unforeseeable manner, and perhaps too unconsciously. Hence, it is difficult to explain certain alternations otherwise. Hence too, the feeling of strangeness we often have about theses texts, a feeling often increased by other phenomena that will not concern us here. This, we believe, is a trend of the writing practices of Burkinabè novelists; hybrid and métisse practices that three other types of temporal alternations help clarify. These temporal alternations are characterized in the Burkinabè novel by a competition between two tense sub-systems of the French language.

\section{Two tense sub-systems occur in the Burkinabè novel When PP substitutes for PLP}

In Burkinabè novels, PP's competition does not concern SP alone, but PLP also, both in terms of its value as a realized present and its use to express retrospection from the zero point of the narration. From Monique Ilboudo's Le mal de peau (131):

On arriving in this country, Cathy had two ambitions: assimilate the second culture, which would perfect her ambivalence, and find her father. For her, these were two imperatives in her search of her identity. Having suffered from estrangement and sectarianism on the one hand, she had hoped for a better welcoming on the other hand. But instead of hope, only contempt and rejection have come her way. This profound disappointment was certainly the reason for the sudden feeling of nostalgia. ${ }^{28}$ 
From Jean Hubert Bazié's Zaka "La maison" (45):

Months have gone by, punctuating a routine life brightened up by children with constantly renewed joy. The season was now fully rainy. Awa regularly placed the utensils under the roof to collect the rain's water. The water vendors had reduced their prices. ${ }^{29}$

From Marie-Ange Somdah's Le nombril de la terre ("The navel of the earth", 1991: 7-8): He was walking slowly in the dark night, a heavy blanket that his legs, weakened by his age, still seemed able to bear. He was born at a time when the earth kept its entire fecundity, and human being, all his virtues. Sowing and harvesting relentlessly punctuated the seasons [...]. That night, Soryul the old man had not closed his eyes [...]. The wind broke up, and soon, began to blow mightily. ${ }^{30}$

The first two excerpts illustrate a case of substitution for a realized PLP, and the last one shows competition against PLP as an indicator of analepsis in narratives based on the SP/IMP pair.

\section{Competition within subordinate clauses}

The issue here relates to what traditional grammar refers to as "tense agreement," when the verb of the main clause is conjugated in a past tense. The Grammaire méthodique du français ("Methodical French Grammar") phrases this as follows:

Tense agreement regulates the change of verbal tenses. When the introducing verb (or the context) is in the present or future tense, the verb does not change: He says: "You are wrong." $\Leftrightarrow$ He says that you are wrong. When the main verb is in a past tense, the tense of the subordinate clause changes depending on the relation between the moment when the discourse is enunciated and the moment when it is reported. The following agreement rules therefore apply: He said: "I am gone" / "I am going" / "I will go." He said that he was gone / he was going / he would go. The tense system of the direct speech is transferred to the past, following the three basic chronological relations of the event subordinated to the main verb: anteriority: the pluperfect replaces the present perfect, simultaneity: the imperfect replaces the present, posteriority: the conditional replaces the future, to indicate "the future seen from the past." This transposition mechanism may experience perfectly logical breaches. (Riegel et alli 1994: 599-600) ${ }^{31}$

We may conclude from this type of description that there is a real willingness for homogenization, which many Burkinabè novels tend to question. The tense transposition that so many grammarians claim does not always occur (see Somé 2006). ${ }^{32}$ Sometimes PP is preferred to PLP as in Zaka "La maison" (45-47): 
Then one evening, Basga has come running to announce that people have said that Adam is dead at the hospital. That there is a crowd at his home [...]. From time to time the donkey scratched the ground with its forelegs as if it could feel this universal call of pain, though its skin has been tanned since its early youth by the repeated beatings on its spine and hindquarters. ${ }^{33}$

Other times, the PRES replaces the IMP in La dérive des Bozos (20):

That is why that evening Bama had his brother Kongwini told that he has nothing but that tomorrow, he will have the bottom of his granary swept so as to send him some millet grains. The other answered, saying that it was preferable for him to keep the remainder of his granary for himself, because it is not good for brothers to despoil themselves in such a manner. The audience laughed wholeheartedly. ${ }^{34}$

Compare in this regard also Bila Roger Kaboré's Indésirables ("The undesired ones", 1990: 97):

Oh! Exclaimed she, ironically, I do not trust glib talkers. But I am not a braggart. I have already told you that I actually meant what I say. Have you never been told that your smile was charming and that your face was beautiful? ${ }^{35}$

Or else, the FUT is preferred to the COND as in Patrick Ilboudo's Le héraut têtu (183):

The day following his access to power, the imperialist press had written that it would not be convenient to allow for such a regime to settle in Bougouriba. Certain conservative spheres on the continent had thought that the revolution and unity stated in the regime's agenda will, for the best, be a nice ritual, and for the worst, a nice joke, or at least an appropriate development machine. ${ }^{36}$

See also Patrick Ilboudo's Les vertiges du trône ("The giddiness of the throne", 1990: 119):

Tell me. Well, I am going to try to reconcile my faithfulness to my roots with what I have become. I was five years old. Benoit Wédraogo had then decided that I will be a farmer in the good old tradition of the Bogya families $\left[\ldots . . .{ }^{37}\right.$

\section{The IMP/PRES in descriptive passages}

In all the preceding enunciations of this third part, two temporal sub-systems are competing: the present sub-system (PP-PRES-FUT) and the past sub-system (PLP-SP/ IMP-COND). Competition also obtains in the descriptive passages of Burkinabè novels; competition between the PRES and the IMP, as in the following two excerpts, the first from Bazié's short novel, Champ d'août and the second from Vincent Ouattara's 1994 novel, Aurore des accusés et des accusateurs ("The dawn of the accused and accusers") $:^{38}$ 
The CIVIL SERVANT was a god. Indeed, he was the black hand serving the white man who has mistreated the black man for the white man! So many blows have been given to have the millet and all these commodities provided for! When the District Officer sends his representative to the district chief, the district chief sends his agents, whips in hand, to the villages. The village chief who does not comply [...] When the District Officer requires one hundred bags per district for the prisoners, the students and civil servants, the agents re-adjust the tribute to be paid: the big village supplies all the one hundred bags, the small ones gave variable smaller quantities that ended up in the pockets of the damn ones! For this you could see adult persons, elderly persons being beaten up, and who were crying, calling their fathers and mothers, under the renewed blows of the envoys of the district chief [...] (Champ d'août, 10-11);

A few minutes elapsed before the van arrived full of soldiers carrying truncheons and tear gas. They are always full of joy when they are called in for such operations; their lives being monotonous, they took advantage of these occasions to move and make themselves useful to society. (Aurore des accusés et des accusateurs, 190) ${ }^{39}$

\section{Conclusion}

I do not mean to deny that there are grammatical mistakes in the temporal transitions of Burkinabè novels. ${ }^{40}$ My analysis purports to help check the more or less implicit trend of condemning some of the tense usages, which, though clearly the result of a fanciful use of the language, always remain within the bounds of linguistic appropriateness. These usages somehow reveal the immense language potentials, which are often not tapped in the standardized usage of French. Considered as a turbulence zone in Burkinabè novels because of their unforeseeable nature, these temporal alternations encompass two main phenomena. On the one hand, there are the transitions operating on the basis of the PP/SP pair in the narration of events, and on the other hand, there are those involving three other temporal pairs (PP/PLP, FUT/COND, $\mathrm{IMP} / \mathrm{PRES}$ ) in grammatical (subordinate clauses) or narrative (descriptive passages) micro-structures. The explanatory principle used here is alternation-telescoping between autonomous diegesis (de-centering the narration from the narrative moment, with SP) and linked diegesis (rooting the narration in the situation of the fictitious enunciation, with SP, as if the narrator did not want to let the events narrate themselves) or between two French temporal sub-systems (the present centering on the PRES and the past centering on the SP/IMP pair).

The general hypothesis behind this analysis is that orality springs up into writing more or less regularly, depending on the narrator. (For a hypothesis closer to this one, see Gandonou 2002: 245.) Hence, the heterogeneous nature of the writing practice of 
Burkinabè authors, which it seems, is a feature of the identity of the Burkinabè novel and may be linked to the dual cultural background of the authors: a written culture acquired through schooling, and an oral culture stemming from the Burkinabè tradition.

The Burkinabè novel is therefore the product of a double métissage, the first aspect of which, it would seem, concerns what it shares with the entire francophone African literature, steeped as it is in Western modernity and African culture. The second facet of the métissage, which still remains to be proved as something exclusively Burkinabè, relates to the authors' strong impulse toward "spontaneous oralized writing," often without their awareness.

Translated by Amadou Bissiri

\section{Notes}

1. Fictional levels that each writer invents and which differentiate them in narratological analyses.

2. “On distinguera ici deux types de récits: l'un à narrateur absent de l'histoire qu'il raconte (exemple: Homère dans l'Iliade, ou Flaubert dans l'Education sentimentale), l'autre à narrateur présent comme personnage dans l'histoire qu'il raconte (exemple: Gil Blas, ou Wuthering Heights). Je nomme le premier type, pour des raisons évidentes, hétérodiégétique, et le second homodiégétique" (Genette 1972: 252). In this and all subsequent quotations emphases have been added, unless stated otherwise.

3. Though some of the observations may be transposed to certain intradiegetic narrators.

4. Among the authors of these novels, two - Patrick Ilboudo and Kollin Noaga - never use SP as their main tense.

5. Sadjo is the main intradiegetic narrator of Le héraut têtu, the only intradiegetic narrator included in my corpus on account of the central position he holds in the novel. He does most of the narration.

6. Caitucoli (1988: 264) numbers $197 \mathrm{SP}$ and $212 \mathrm{PP}$ in the first and third parts of Le miel amer.

7. Dieudonné Samou Tamini, the young author of Pour nous la galère, his first published novel, only rarely gives his intradiegetic narrator the opportunity to use PP in SP dominated narratives.

8. "Retiré du français parlé, le passé simple, pierre d'angle du Récit, signale toujours un art; il fait partie d'un rituel des Belles-Lettres. Il n'est plus chargé d'exprimer un temps" (Barthes 1972: 25).

9. A translation difficulty: Tenses do not operate in the same manner in French and English. For the sake of practicality, in translating the quotations the translator has purposely kept the tenses as they are used in the French version [transl.].

10. “Tôt levé, Batolo est allé réveiller son oncle. Ils ont rendez-vous ce matin avec la vérité historique au Palais de Justice où le tribunal de la révolution populaire permanente doit rendre le verdict du procès opposant l'Union Economique Africaine à Biga Zambsoiba et Pass Yam [...] Débouchant sur la rue qui mène au palais de Justice, ils s'aperçoivent qu'une maree humaine avait déjà pris d'assaut la salle d'audience [...] un brouhaha de jour de marché campagnard ou de marché aux puces envahit le climat. Les animateurs de la radio ajoutent au vacarme leurs commentaires au vitriol. Brusquement le silence se fit pour laisser parler, la seule voix de la présidente du tribunal. [...] Une tempête d'exclamation suit l'annonce publique du jugement. Batolo et Ram Nogdo qui sont perdus dans le rassemblement doivent être_approximativement satisfaits" (Ilboudo 1987: 224226). These occurrences are common in Père, je te pardonne tout ("Father, I forgive you for everything", 1994). In Les vertiges du trône ("The giddiness of the throne", 1990), a novel in PRES/PRES, the narration gradually shifts to an SP/IMP base over seven pages. Le retour au village ("Back to the Village", 1978) and Haro, camarade commandant ("Shame on you, Comrade Commander", 1977) also often use the PS/IMP base, alternating it for apparently stylistic purposes.

11. "This is perhaps one of the linguistic characteristics of these texts, which has led some analysts to assert that verbal temporality constitutes a kind of "turbulence zone" or else: "What strikes the linguist that I am on reading Le miel amer is that the tense and mode system is used in way that a 
classic grammarian would deem incorrect, but that I see as atypical, that is, devoid of any value judgment, or as non-ordinary, considering the entire French-speaking novel production." ("Ce qui frappe le linguiste que suis à la lecture du Miel Amer, c'est que le système des temps et de modes est utilisé d'une façon qu'un grammairien classique pourrait qualifier d'incorrecte, que je qualifierai pour ma part d'atypique, c'est-à-dire sans aucun jugement de valeur, de non ordinaire, eu égard à l'ensemble de la production romanesque d'expression française. Ce jugement vaut à mon sens pour l'ensemble du système verbal.") (Caitucoli 1998: 261).

12. "Les temps d'un verbe français ne s'emploient pas comme les membres d'un système unique, ils se distribuent en deux systèmes distincts et complémentaires" (Benveniste 1966: 238).

13. "L'énonciation historique, aujourd'hui réservée à la langue écrite, caractérise le récit des événements passé. Ces trois termes, 'récit', 'événement', 'passé', sont également à souligner. Il s'agit de la présentation de faits survenus à un certain moment du temps, sans aucune intervention du locuteur dans le récit [...] Il faut entendre par discours dans sa plus large extension: toute énonciation supposant un locuteur et un auditeur, et chez le premier l'intention d'influencer l'autre en quelque manière [...] Chaque fois qu'au sein d'un récit historique apparaît un discours, quand l'historien par exemple reproduit les paroles d'un personnage ou qu'il intervient lui-même pour juger les événements rapportés, on passe à un autre système temporel, celui du discourse." (Benveniste 1966: 242)

14. "Le propre du langage est de permettre ces transferts instantanés" (Benveniste 1966: 242).

15. Clearly, an important note of the first volume, Problems of General Linguistics, has not been read carefully: "We are always talking about the tenses of 'story narrative' to avoid the term 'narrative tense,' which has resulted in much confusion. For our purpose here, the indeterminate [SP] is a 'narrative tense,' but the perfect [PP] may as well be one, which would end up obscuring the fundamental distinction between the two enunciation levels." ("Nous parlons toujours des temps du 'récit historique' pour éviter le terme 'temps narratifs' qui a créé tant de confusion. Dans la perspective que nous traçons ici, l'aoriste [PS] est un 'temps narratif', mais le parfait [PC] peut aussi en être un, ce qui obscurcirait la distinction essentielle entre les deux plans d'énonciation." (Benveniste 1966: 242n)

16. "Prendre en compte deux modes diégétiques me paraît utile pour sortir de l'impasse des deux plans d'énonciation habituellement cites - 'discours' ou 'commentaire' vs 'histoire' ou 'récit' - et des deux sous-systèmes verbaux qui en découlent [...].En conservant les plans d'énonciation traditionnels, on admet en effet que le PC est un temps du 'discours' et le PS un temps de l' 'histoire'. Cette dichotomie, trop stricte, qui ne tient pas compte, par exemple, des deux valeurs du PC, débouche inévitablement sur des aberrations. C'est ainsi que A.-M. De Both-Diez, parle d'un PC de 'discours' et d'un PC 'historique'. Afin d'éviter toute ambiguïté, je propose de distinguer au total trois modes énonciatifs: direct, lié, autonome." (Revaz 1996: 190)

17. "mode le plus direct de repérage, dont les paramètres de base sont ceux de l'interaction verbale: l'ancrage déictique primaire je-tu / vous + ici + actuellement." (Adam, Lugrin and Revaz 1998: 88)

18. "Pour construire un monde révolu passé ou fictif, on a le choix entre une diégétisation sur un mode actualize-c'est-à-dire rattachée, liée à l'actualité d'un narrateur-et une diégétisation sur un mode non-actualisé-c'est-à-dire détachée de l'actualité de la voix énonciative.' En francais, ces deux de diégétisation correspondent à l'opposition du PC et du PS car, comme le notait déjà Benveniste de façon certes encore un peu succincte: 'Le repère temporel du parfait [PC] est le moment du discours, alors que le repère de l'aoriste [PS] est le moment de l'événement' (1966: 244)" (Adam, Lugrin and Revaz 1998: 90)

19. For (Adam, Lugrin and Revaz 1998: 85) we are even compelled to postulate the existence of a $4^{\text {th }}$ sub-system: "It is difficult to ignore the existence of a fourth sub-system, which in some aspects, is close to 'discourse' (actualized or actualizable discursive representation) and, in others, is close to 'story' (a distanced enunciation attitude in both cases). The main difference lies in that the temporality of the 'story' level is a real or fictitious past. The validity of the enunciations in the defining PR and gnomic PR modes is fully open; it involves the past, the present, and the future. This temporality or rather, this omni-temporality is the main source of the distinction between this sub-system and the other three." ("On peut difficilement ignorer l'existence d'un quatrième sous-système, proche par certains côtés du 'discours' (représentation discursive présentifiée ou présentifiable) et par d'autres de l' 'histoire' (attitude énonciative également distanciée dans les deux cas). La différence majeure réside dans le fait que la temporalité du régime 'histoire' est un passé réel ou fictionnel; la validité des énoncés au PR de définition et au PR gnomique est totalement ouverte, elle recouvre aussi bien le passé, que le présent et le futur. Cette atemporalité 
ou plutôt cette omnitemporalité est la source principale d'une différenciation de ce sous-système par rapport aux trois autres."

20. The issue of diegesis operating on the PRES/PRES base still remains to be solved. For a presentation of this type of diegesis, see Gosselin (2005: 205-218). He indicates how the PRES occurs between "presentation" and "representation.

21. See the six simple pasts that the narrator of L'étranger has "forgotten," and which Adam (1977: 175177) analyses.

22. "La foule se dissipa en silence. Ni le lieu ni le moment ne se prêtaient aux commentaires. Chacun donnera son point de vue dans sa case avec l'avarice de sons qu'exigeait la discrétion.

Le coumandow a remis aux pages de Liguidy une grande bassine, une lampe tempête neuve, six cuillères et un litre de vin. C'étaient des cadeaux habituels qu'il donnait à son ami pendant les grandes fêtes ou en récompense aux nombreux services rendus.

Liguidy entouré des notables des quartiers et des villages, a écouté dans un recueillement total ses griots chanter ses louanges. Il fallait cette douce pluie pour atténuer les flammes qui s'étaient allumées dans ses veines depuis l'annonce du «forfait des gourounsis.

"Je vous ai fait venir pour vous dire en clair [...] Liguidy a parlé. Vous pouvez rentrer chez vous." Les notables ont promis leur soutien inconditionnel au coumandow et à Liguidy. Mais hors du palais, chacun avait sa petite idée sur ces événements, idée qu'il se gardait pourtant d'extérioriser" (Zongo 1990: 148-153).

23. The other passages of the excerpt concern the indirect reported speech, where the same type of alternation obtains. For a study of this excerpt from this perspective, see Somé (2005: 115-140).

24. "Kiéta jura. Alors le juge lui dit [...] Kiéta a précisé qu'en toute sincérité [...] Les juges lui posèrent alors [...] Le président du tribunal lui demanda [...] L'un des juges demanda [...] Kiéta répondit [...] Le juge développa [...] Le vieux a expliqué que [...] Il expliquait à 'ses fils' que [...] Le vieux a dit [...]." (Bazié 1986a: 60-69)

25. “Une nuit, Fanta s'est éloignée de la concession. Bakary observait. Il lui emboîta le pas à distance et l'épia. Fanta s'est dirigée vers la voie à grand trafic qui traverse le quartier [...] Fanta a pressé [...] Elle y est parvenue et elle a demandé le Dormeur, quotidien de la place le plus complet. Elle l'acheta. Rapidement elle le feuilleta et elle parvint à la page des services [...] Après, Fanta a camouflé le paquet dans son porte-monnaie et a repris les chemins de la nuit. Elle arriva à la maison et s'engouffra dans sa chambre. L'oncle Bakary arriva [...] Fanta se mit à pleurer à chaudes larmes. Le bruit $a$ alerté les gens de la concession. Les épouses de Bakary sont accourues; les enfants aussi. Déjà, les voisins commencèrent à s'inquiéter [...] Avant de partir, l'oncle Bakary s'est approché de sa sœur et lui $a$ dit [...] Fermement, elle répondit rassurante [...] Et elle s'en alla. " (Bazié 1964: 132-138) L'épave d'Absouya is an extra-homodiegetic narrator novel in which the narrator is not the only main character (the other one is Taram, a friend of the narrator's). That is why the novel contains many P3 passages. For an illustration of a swinging between autonomous diegesis and linked diegesis under P1, see p. 64 of the novel.

26. “c'est le lecteur de Benveniste qui se trouve embarrassé, car le passé simple et le passé composé apparaissent dans la même phrase, sans que rien ne justifie un changement de type énonciatif. Et il ne s'agit pas d'un dérapage accidental [...]" Caïtucoli (1988: 263). See Caitucoli (1988: 263) for the writing style of Jean-Baptiste Somé in Le miel amer.

27. “On l'a vu avec l'exemple de Michel Leiris, les glissements fréquents d'une narration au PS à une narration au PC (et l'inverse bien sûr) ne s'expliquent pas autrement. Si les deux emplois s'excluent du point de vue de la position du sujet de l'énonciation, ils s'attirent en revanche du point de vue de la diégétisation qu'ils assurent l'un et l'autre. Leur cohabitation n'est donc pas si extraordinaire ni si absurde qu'on ne le dit généralement en appliquant un peu trop mécaniquement les dichotomies de Benveniste et Weinrich." (Adam, Lugrin and Revaz 1998: 96)

28. "En arrivant dans ce pays, Cathy avait deux ambitions: assimiler la seconde culture qui devait parfaire son ambivalence, et retrouver son père. C'était pour elle les deux impératifs dans la recherche de son identité. Ayant souffert de l'isolement et du sectarisme d'un côté, elle avait espéré un meilleur accueil de l'autre. Or voilà qu'à cet espoir, n'ont répondu que mépris et rejet. Cette profonde déception était certainement la cause de la brusque apparition de la nostalgie." (Ilboudo, M. 1992: 131)

29. "Les mois ont passé, rythmant une vie de routine égayée par les enfants à la joie toujours renouvelée. C'était maintenant le plein hivernage. Awa mettait régulièrement les ustensiles sous les tôles pour récupérer l'eau pendant les pluies. Les vendeurs d'eau avaient baissé les prix." (Bazié 1991: 45) 
30. "Il avançait lentement dans la nuit noire, une pesante couverture que semblaient supporter encore ses jambes affaiblies par l'âge. Il est né à l'époque où la terre conservait encore toute sa fécondité et l'être humain, toutes ses vertus. Les semailles et les récoltes rythmaient sans failles les saisons [...] Cette nuit-là, le vieux Soryul n'avait pas fermé l'œil [...] Le vent se leva et, aussitôt, se mit à souffler avec force." (Somdah 1991: 7-8)

31. "Le changement des temps du verbe est réglé par la concordance des temps. Quand le verbe introducteur (ou le contexte) est à un temps du présent et du futur, le verbe ne subit pas de changements: Il affirme: 'Tu as tort' $\Leftrightarrow$ Il affirme que tu as tort. Quand le verbe principal est à un temps du passé, la subordonnée subit des changements de temps suivant la relation entre le moment où le discours a été énoncé et celui où il est rapporté. On établit les règles de concordance suivantes: Il a dit: 'Je suis parti' / 'Je pars' / 'Je partirai'. Il a dit qu'il était parti / qu'il partait / qu'il partirait. Le système des temps du discours direct est décalé au passé, suivant les trois rapports chronologiques de base du fait subordonné au verbe principal: antériorité: le plus-que-parfait transpose le passé composé, simultanéité: l'imparfait transpose le présent, postériorité: le conditionnel transpose le futur, pour indiquer le 'futur vu du passé'. Ces règles de transposition mécanique peuvent connaître des entorses parfaitement logiques." (Riegel et alli 1994 : 599-600)

32. Somé (2006) builds on the recent developments by Gosselin (1996), Berthonneau \& Kleiber (1997), Rosier \& Wilmet (2003).

33. "Puis un soir, Basga est venu en courant annoncer qu'on a dit qu'Adama est mort à l'hôpital. Qu'il y a du monde chez eux [...]L'âne de temps en temps grattait le sol de ses pattes avant comme s'il entendait cet appel universel de la douleur, lui dont la peau a été tannée depuis sa tendre jeunesse par les coups répétés sur l'échine et l'arrière-train. (Bazié 1991: 45-47)

34. “(17) C'est pourquoi ce soir là, Bama fit répondre à son frère Kongwini qu'il n'a rien mais demain, il fera néanmoins balayer le fond de son grenier pour lui procurer quelques grains de mil. L'autre répondit en disant qu'il était préférable de garder pour lui-même ce fond de grenier car il n'est pas bon pour des frères de se dépouiller de cette manière. L'assistance rigola à gorge déployée." (Bazié 1988: 20)

35. “(24) Oh là ! Ironisa-t-elle, je me méfie des beaux-parleurs. Mais je ne suis pas un hâbleur. Je t’ai déjà dit que je pensais vraiment ce que je dis. On ne t'a jamais dit que ton sourire était charmant et que ton visage était joli." (Kaboré 1990: 97)

36. "Le lendemain de son avènement au pouvoir, la presse impérialiste avait écrit qu'il ne serait pas seyant de permettre qu'un tel régime s'installe dans la Bougouriba. Certains milieux conservateurs du continent avait pensé que la révolution et l'unité inscrites au programme du régime seront au mieux un aimable rite, au pire une bonne plaisanterie, à la rigueur une machine appropriée pour le développement." (Ilboudo, P. 1991: 183)

37. "Dites-le moi. Bon, je vais essayer de concilier la fidélité à mes origines avec ce que je suis devenue. J'avais cinq ans. Benoît Wédraogo avait alors décidé que je serai une paysanne dans la bonne tradition des familles de Bogya [...]." (Ilboudo, P. 1990: 119)

38. This rather surprising substitution game between IMP and PRES obtains, outside the fiction, in Norbert Zongo's writing practice. He explained the reason of this to Hyacinthe Sanwidi in an interview: "There too I want to use a kind of ambivalence to answer you. Yes, I impose because I have written. Some French people have read my writings. Like any writing, it is a kind of expansion of the author's personality. My personality, whether I like it or not, contains imprints of my Moaaga origins. And in light of what I was saying right now, I am often compelled to awkwardly think in Mooré when I am writing in French. And the French language, as you know, at some point in time, the Puritans, the French Academy, tried to sanction this way of writing, which was not French, but eventually, this Africanized French has imposed itself to the French Academy. If I take the example of Les soleils des indépendances, and what Kourouma said. He roamed the world with his manuscript, and editors kept rejecting it, and finally Le soleil des indépendances came out and won a prize and [...] if we also take Batouala by René Maran in the 1920s, we can see that there is part of the author's personality, part of his culture, of 'imposed language,' which the author, in turn, imposes. That's why I say, yes. And then no, I do not impose. Why? Because, as we were saying, whether we like it or not, the French language imposes itself to me in a certain context. There we are, it's a little ambivalent, but we can understand it." (Sanwidi 1993: 103-115) ("Là encore je vais utiliser une espèce d'ambivalence pour répondre. Oui, j'impose parce que j'ai écrit, il y a des Français qui $\mathrm{m}^{\prime}$ ont lu et comme toute écriture, c'est une espèce d'épandage de la personnalité de l'écrivain. Or ma personnalité, que je le veuille ou non, il y a cette empreinte du Moaga dans ma personnalité. Et compte tenu de ce qu'on venait de dire, je suis souvent obligé de façon maladroite de 
penser en moore en écrivant en français. Et la langue française aujourd'hui, à un certain moment les puritanistes, l'Académie française a voulu sanctionner cette façon d'écrire qui n'était pas le français, mais finalement ce français africanisé s'est imposé au niveau de l'Académie française. Et je prends pour exemple Les soleils des indépendances, ce que Kourouma disait. Il a traîné partout avec son manuscrit et chaque fois on le lui rejetait et finalement Les soleils des indépendances a paru avec un prix et [...] même si on revenait à Batouala de rené Maran des années vingt, on voit qu'il y a cette part de personnalité, il y a cette part de culture, de la langue imposée à l'écrivain entre griffes et que l'écrivain à son tour impose. C'est pourquoi je dis oui. Et ensuite non je n'impose pas. Pourquoi? Parce que, comme on venait de le dire, qu'on le veuille ou non, la langue française s'impose à moi dans un certain contexte. Voilà, c'est un peu ambivalent mais ça s'explique.")

39. "Le FONCTIONNAIRE était un Dieu. En fait, c'était le bras noir au service du blanc qui a malmené le noir pour le blanc! Combien de coups ont été donnés pour faire rentrer le mil et tous ces vivres, quand le commandant envoie son représentant au chef de canton, le chef de canton envoie ses agents munis de cravaches dans les villages. Le chef de village qui ne s'exécute pas [...] Quand le commandant demande cent tines par canton pour les prisonniers, les élèves et les fonctionnaires, ces gens-là vont recomposer le tribut à payer: le gros village donne tous les cent tines, les petits donnaient des quantités inférieures variables qui allaient dans les poches des damnés! On voyait battre pour cela de grandes personnes, des personnes âgées qui criaient leur père et leur mère, sous les coups redoublés des envoyés du chef de canton [...]” (Bazié 1986a: 10-11);"Quelques minutes s'écoulèrent avant l'arrivée des fourgons remplis de soldats munis de matraques et de gaz lacrymogène. Ils rayonnent toujours de joie lorsqu'on leur fait appel pour ce genre d'opération; leur vie étant monotone, ils profitaient de ces occasions pour se mouvoir et se rendre utiles à la société." (Ouattara 1994: 190)

40. Somé (1998: 374-402) presents some of these non-grammaticalities in an attempt to provide a linguistic explanation of a number of occurrences, in terms of non-resolved conflicts between many instructions of the enunciation.

\section{Works cited}

Adam, J-M. 1997. Le style dans la langue. Une reconception de la stylistique. Lausanne-Paris: Delachaux et Niestlé.

2005. La linguistique textuelle. Introduction à l'analyse des discours. Colin: Cursus.

Adam, J-M., Lugrin G., Revaz F. 1998. Pour en finir avec le couple récit/discours. Pratiques n 100: 81-98.

Barthes, R. 1972 [1953]. Le degré zéro de l'écriture suivi de Nouveaux essais critiques. Paris: Seuil.

Benveniste, E. 1966. Les relations de temps dans le verbe français. Problèmes de linguistique générale t. 1. Paris: Gallimard, 237-250.

Caitucoli, C. 1988. Passé simple et passé composé dans Le miel amer de Jean-Baptiste Somé. Annales de l'Université de Ouagadougou (Série A Sciences Humaines et Sociales). Numéro spécial, 261-275.

Gandonou, A. 2002. Le roman ouest-africain de langue française. Etude de langue et de style. Paris: Karthala.

Genette, G. 1972. Figures III. Paris: Seuil (Poétique).

Gosselin, L. 2005. Temporalité et modalité. Bruxelles: Duculot.

Revaz, F. 1996. Passé Simple et Passé Composé: Entre Langue et Discours. Etudes de Linguistique Appliquée $n^{\circ}$ 102: 175-198.

Riegel, M., Pellat J.-C, Rioul R. 1994. Grammaire méthodique du français. Paris. PUF.

Sanwidi H. 1993. Trois Ecrivains Burkinabè Et La Langue Française. Cahiers de linguistique sociale. Numéro Spécial (Le Français Au Burkina Faso). Cnrs Université De Rouen, Coll. Bilans et Perspectives, 103-115

Somé, K. P. 1998. Temporalité verbale et récit. Le fonctionnement du système verbal du français dans les romans burkinabè. Unpublished doctoral dissertation. Paris: Université de Cergy-Pontoise.

. 2005. Le dialogisme à l'œuvre dans les romans burkinabè. In P. Haillet (éd.). Regards sur l'héritage de Mikhaïl Bakhtine. Paris: Université de Cergy-Pontoise, 115-140.

2006. Aux prises avec la concordance des temps "a pour ambition de relativiser le problème de la grammaticalité des pratiques discursives de romanciers burkinabè qui ne respectent pas la "concordance des temps" (Pending). 


\section{Burkinabè novels (1962-1995)}

Bamoumi, Babou Paulin. 1987. Obou l'étudiant journaliste. Ouagadougou: Avant-Garde.

Barrot, Pierre et Drame, Seydou. 1993. Bill L'espiègle. Paris: Lieu Commun, Edima.

Bazié, Jacques Prosper. 1988. La dérive des Bozos. Ouagadougou: Edition Kraal. 1994. L'épave d'Absouya. Ouagadougou: Edition Kraal.

Bazié, Jean Hubert. 1986. Champ d'août. Ouagadougou: N. p. . 1991. Zaka "La maison". Ouagadougou: Imprimerie Centrale.

Bonkian, Jean Luc. 1993. Le fil des crevasses. Ouagadougou: co-edition ets Socifa et Edit. Sidwaya.

Coulibaly, Augustin Sondé. 1974. Les dieux delinquents. Ouagadougou: Imprimerie Nationale.

Damiba, Geoffroy. 1990. Patarbtaalél le fils du Pauvre. Ouagagdougou: Imprimerie Nouvelle Du Centre. . 1992. Le geste interdit. Ouagadougou: Imprimerie Nationale. 1995. Père je te pardonne tout. Ouagadougou: Imprimerie Nationale.

Hien, Ansomwin Ignace. 1988. L'enfer au paradis. Ouagadougou: Presses Africaines. . 1989. Au gré du destin. In Didier Lezin et Ignace A. Hien. Paris: Ouvrage Imprimé sur les presses de L'imprimerie Chazelle, 71-154.

Ilboudo, G. Patrick. 1987. Le procès du muet. Ouagadougou: La Mante. . 1988. Les carnets secrets d'une file de joie. Ouagadougou: La Mante. 1990. Les vertiges du trône. Ouagadougou: Imprimerie Nationale du Burkina, La Mante. 1991. Le héraut têtu. Ouagadougou: Imprimerie nouvelle du centre.

Ilboudo, Monique. 1992. Le mal de peau. Ouagadougou: Imprimerie Nationale.

Ilboudo, Pierre Claver. 1985. Le fils aîné suivi de Le mariage de Tinga. Paris: Silex. . 1987. Adama ou la force des choses. Paris: Présence Africaine.

Kaboré, Bila Roger. 1990. Indésirables. Paris. L'Harmattan.

Kollin, Noaga. [ps. Nongma Ouédraogo]. 1977. Haro! Camarade Commandant. Ouagadougou: Presses Africaines. 1978. Le retour au village. Paris: Imprimerie Saint Paul.

Nazi, Boni. 1962. Crépuscule des temps anciens. Paris: Présence Africaine.

Nikiéma, Roger. 1967. Dessein contraire. Ouagadougou: Presses Africaines.

Ouattara, Vincent. 1994. Aurore des accusés et des accusateurs. Paris: L'Harmattan.

Ouedraogo, Yamba Elie. 1991. On a giflé la montagne. Paris: L’Harmattan.

Rouamba, Pawindbé Fidèle. 1995. Le carnaval de la mort. Ouagadougou: Imprimerie nouvelle du centre.

Sawadogo, Etienne. 1977. La défaite du Yargha. Ouagadougou: Etienne Sawadogo et la "Pensée Universelle".

Somdah, Marie-Ange. 1992. Ajoa, l'aurore. Besançon: Couleur locale. 1994. Le nombril de la terre. Paris: L’Harmattan. 1998. Campus Blues. Paris: Nouvelles du Sud.

Somé, Jean-Baptiste. 1985. Le miel amer. Québec: Naaman de Sherbrooke. . 1990. Affaire de coeur. Ouagadougou: Presse de l'Imprimerie Nationale du Burkina.

Tamini, Dieudonné Samou. 1990. Pour nous la galère. Ouagadougou: Imprimerie Rapide du Burkina. Zongo, Norbert. 1988. Le Parachutage. Ouagadougou: Edition ABC. . 1990. Rougbêinga. Ouagadougou: Imprimerie nouvelle du centre. 